\title{
The United States' Policy towards the World Trade Organization during the Presidency of Donald Trump ${ }^{1}$
}

\begin{abstract}
The purpose of this article is to analyze the United States' policy towards the World Trade Organization (WTO) during the presidency of Donald Trump. Given the stated aim, research questions allow to identify the significant priorities of American foreign policy within the Organization, trade policy challenges, and the current and future survival of the global exchange system. Hence, the article is focused on: the importance of the WTO for the global exchange system; the role and capabilities of the United States (US) in the Organization's analysis; and identification of main priorities and challenges of the US foreign policy towards the WTO in the context of the current trade rivalry with China and its impact on the WTO's future. The main hypothesis of the article indicates that the current US trade policy weakens the possibilities and further functioning of the WTO. The main theoretical perspective of the article is based on institutional liberalism and the theory of comparative advantage. The article has been developed by applying historical, institutional, and legal systemic and content analysis methods (in particular, government, WTO, and think tank reports and analyses).
\end{abstract}

Key words: World Trade Organization, Donald Trump, trade, tariffs, United States, USTR, liberalization, protectionism

\section{Introduction}

Nowadays the US trade policy is a topic widely discussed by both political scientists and economists. However, the question still remains as to where the US foreign and economic policy is heading and whether economic liberalism can be affirmed as the current global trend. This article contributes towards narrowing the research gap in

\footnotetext{
1 The work was financed by a subsidy of the Faculty of International and Political Stud-
} ies of the Jagiellonian University for doctoral research activities. 
view of the topicality and dynamism of the issues raised. However, it is worth emphasizing that the global trading system is a topic frequently undertaken for research by both European and Polish researchers. The purpose of this article is to analyse the US trade policy towards the WTO during the presidency of Donald Trump. Taking into consideration the aim and content of the article, the main research questions include: 1) Can the US policy and reform proposals contribute to increasing the effectiveness of the WTO? 2) Do the reforms serve current American political interests? and 3) What is the future of the WTO in light of the US-China economic rivalry? This article consists of an introduction, main body that focuses on selected aspects of US foreign policy, and conclusion. The introduction indicates the major substantive and methodological assumptions of the article, hypotheses, and research questions, as well as the theoretical perspective that relates to the importance of the neoliberal doctrine (institutional liberalism) and international economics. Further, the article focuses on the significance of the WTO in global exchange, pointing to the formal foundations of the system's functioning, the genesis of its creation, individual tasks, and the dispute resolution system.

The next part addresses the fiasco that was the Doha negotiations and its effects on the credibility and future of the WTO system, particularly in the context of crucial systemic changes and the role of emerging markets. Subsequently, the article assesses the role of the US in the WTO, the powers of the US executive and legislative authority in conducting trade policy, and the main negotiating priorities. Hence, the article highlights the major trade challenges of the Trump administration with particular emphasis on China's current economic position, the proliferation of regional trade agreements, and changes in global supply chains. Considering the issues outlined, the main hypothesis of this study surmises that the US trade policy weakens the possibilities and future functioning of the World Trade Organization. In addition, the supportive hypothesis points out that the priority of US trade policy remains to limit China's economic position and its trade policy. The article has been developed through the following methods: a historical (identification of past economic processes and the origins of the GATT/WTO system); systemic (the importance of the US in the WTO and the global economy in the 21st century); institutional and legal (analysis of the powers of the American Congress, President, and United States Trade Representative, USTR, in the field of trade policy); content analysis (documents from government and independent institutions). The article was prepared on the basis of government reports and analyses available online (in particular the USTR and the Congressional Research Service), think tanks (Council on Foreign Relations, Brookings Institution, the Peterson Institute for International Economics), and the Asian Development Bank. WTO reports and information available on the official website as well as articles from the Foreign Policy magazine remain a valuable source of information.

\section{Institutional liberalism and comparative advantage as a theoretical orientation}

The considerations contained in the analysis below, which relate to Trump's policy towards the WTO, refer to both political and economic sciences. Therefore, to examine the following issues in a comprehensive manner, which address foreign and 
economic policy goals, there is a need to adapt the theoretical orientation in a hybrid manner. Hence, the following article refers to the neoliberal doctrine in political science, in particular institutional liberalism, and the theory of international economics.

According to Jackson and Sorensen, liberals do not reject the possibility of conflicts, however, inter-state rivals, transfer to a different plane of activity by providing different instruments of analysis (Jackson and Sorensen 101). Hence, international conflicts in the 21st century are increasingly geo-economic rather than geopolitical. That is why liberals indicate an important process of classical wars' substitution with state economic expansion, which mainly concerns the most advanced economies such as the US (Keohane and Martin 39). By adapting the theory of institutional liberalism, which was developed by Robert Keohane in 1984, international relations are a "non-zero sum game", which means that all participants are able to achieve some benefit within the international system and its rules. Primarily, mutual cooperation is favored by international institutions, such as the WTO or the International Monetary Fund, which contribute to its intensification at the bilateral, regional, and global levels (Keohane 14). The institutionalization of interrelationships should be examined due to the scale or degree of the intensification, taking into account its scope and depth. Firstly, the scope of institutionalization mainly covers the range of fields that are part of a given institution - for instance, commercial and investment or political and military. On the other hand, the depth of institutionalization is analyzed due to their universality, detail, and level of autonomy of the participants (Baldwin 10). The institutional liberals are convinced that a high degree of institutionalization of mutual international relations reduces destabilization, which is the result of a multipolar structure of the world system. Therefore, the activities of international institutions help to reduce the lack of trust between states by enabling participants, inter alia, to have widespread access to information. In a major way, the guarantors of stabilization are primarily mutual trade agreements and clauses that eliminate insecurity. Thus, it is the state - keeping in mind its foreign policy strategy - that is responsible for initiating and realizing its own interests on the basis of the processes of liberalization. Moreover, the explanatory values of institutional liberalism allow researchers to analyze the priorities and strategies of the US foreign policy towards the authorized institutions regulating the global exchange especially the WTO. In addition, neoliberalism enables the identification of the role and importance of the United States in the institutional system and the analysis of results within contentious issues and other disputes. Moreover, it provides knowledge about the possibilities of restructuring the global economy through extensive internal reforms (Simmons and Martin 195).

On the other hand, the article refers to the theoretical orientation of international economics, in particular classical trade theories. Free trade contributes to the economic wellbeing of the state in many ways. Therefore, one of the biggest advantages of trade is the international price differential that allows exchange participants to use their so-called 'comparative advantage'. Trade provides a country with access to goods and services at relatively low prices, and at the same time allows domestic producers to find profitable export markets where they sell their goods - that have been produced in the country of origin much cheaper than abroad (Rymarczyk 22). To begin with, the theory of comparative advantage was popularized in 1817 by David Ricardo in the book Principles of Political Economy and Taxation. In reality 
however this approach was developed by Robert Torrens. The comparative advantage model is one of the classical theories of trade, according to which the relative ratio of the costs of producing goods, that are exchanged in partner countries, is decisive for the benefits of exchange for two trading partners - not the level of expenditure that should be incurred in individual countries to create goods (Ricardo 2-6). In addition, trade enables the state to achieve higher total consumption of goods and services, which would not be possible without commercial exchange. As a result, it also benefits consumers by increasing the number and variety of goods available in the market (Budnikowski 44-45). It is worth emphasizing, however, that the theory of comparative advantage has many imperfections. Economists point out that this approach favors specialization issues while ignoring the importance of other costs (such as those related to transport and external commercial services). What is more, specialization may cause numerous problems related to structural unemployment (it is more difficult for employees to change jobs by sector). Moreover, the theory of competitive advantage assumes that the market has adequate and fair conditions of competition, which is somewhat of a hasty assumption. The advantage in the international system is not a permanent feature. First of all, some resources may run out and other countries may change production specializations. Thus, it turns out that the theory of comparative advantage is a poor guide of development policy, especially when it does not take into account the development and transfer of knowledge and science (Xie 243-250).

What is more, mutual trade in many ways increases the productivity of domestic companies, including: a) trade transfers production towards goods in which the country has a comparative advantage, which over time, allows both work and capital to be concentrated in more productive sectors of the economy, thereby increasing national income; b) trade enables domestic producers to use new technologies, which allows them to increase their inputs and thus the global competitiveness of products; c) companies that gain access to new markets are able to increase the average since trade allows the most productive companies and sectors to strengthen their share in state production. It also enables productivity, profitability, and wages leading to growth that raises national living standards. Furthermore, companies engaged in export trade that are a huge engine of growth and employment in the economy bring greater benefits to the economy overall (Bernhofen and Brown 7). However, in the case of Donald Trump's actual trade policy and his stance on the WTO, the president's attitude is much more critical - given the possible benefits of free trade. The skeptical attitude towards economic liberalization manifests itself, inter alia, in the beginning of the institutional crisis in the WTO and the trade war with China.

\section{The importance of WTO in international system}

The WTO is an international economic organization based in Geneva, which was established in Marrakesh during the Uruguay Round of the General Agreement on Tariffs and Trade (GATT) in 1994 (Cimino-Isaacs and Fefer 1-2). In practice, the functioning of the WTO began on January 1, 1995 and replaced the previous GATT system, which was established in 1947. Moreover, excluding the mentioned GATT system, the WTO consists of several other agreements: General Agreement on Trade in 
Services - GATS, The Agreement on Trade-Related Aspects of Intellectual Property Rights - TRIPS, The Agreement on Technical Barriers to Trade - TBT, The Agreement on the Application of Sanitary and Phytosanitary Measures - SPS, Agreement on Agriculture and Agreement on Subsidies and Countermeasures - SCM. Currently, the WTO is the leading economic international institution since it covers $98 \%$ of global trade (USTR, 2014, 1-6).

As one of the leading international organizations, WTO deals with the liberalization of international trade in goods and services, investment policy supporting trade, settling disputes regarding trade exchange, and respecting intellectual property law. The WTO Dispute Settlement Understanding (DSU) provides member states with a mechanism to resolve disputes and obligations that arise from belonging to institutions. According to data, the WTO has already considered almost 600 commercial disputes (Matasushita, Schoenbaum and Mavroidis 103). Such disputes are usually resolved through consultations or agreements before formal court proceedings (WTO, "About WTO"). Therefore, when a complaint occurs, there is a requirement to resolve the problem by reconciliation. Finally, if the consultations fail, the case is taken to court. Subsequently, whether or not the recommendations are rejected by authorized WTO bodies, they must be applied by the country that committed the offense (Van Grasstek 1-6). If the country does not comply with the recommendations, the WTO has the right to impose retaliatory measures such as raising tariffs or blocking imports. Although, many experts recognize the current system to be effective, some member states point to the necessity of reform of the internal mechanism due to many procedural deficiencies (Fergusson, World Trade Organization 1-4).

The possibilities of belonging to the WTO are associated not only with the benefits that result from trade liberalization, but also with many legal restrictions. Hence, the WTO member states are required to adapt their internal legislation to trade standards established by the Organization and to grant trade concessions to foreign entities (Eichengreen and Irwin 871-880). Subsequently, the WTO manages existing trade agreements and moreover, serves as a negotiating forum for establishing further trade liberalization deals, reviewing and controlling national trade policies by overseeing the development of global economic policy (Trade Policy Review 6). In addition, the WTO focuses on providing assistance to least developed countries (LDCs) and low-income countries as well as developing countries through technical cooperation and training (WTO 6). What is more, this type of aid enables future compliance with the rules and standards in force in the WTO. Also, in order to achieve greater global coherence, the WTO, cooperates with the International Monetary Fund (IMF) and the International Bank for Reconstruction and Development (IBRD) and other related agencies (USTR, 2018, 7).

Trade in goods, services, and agriculture belongs to the three largest areas of the organization's negotiation agenda. In this regard, the WTO's tasks focus on removing tariff and non-tariff barriers and establishing rules on the commercial practices of individual governments: trade remedies, technical barriers to trade (TBT), intellectual property rights (IPR), and government procurement (Goldstein, Rivers and Tomz 37-45). The particular agreements are based on the principles that prohibit discrimination of cooperation between WTO members under: most-favored-nation (MFN), national treatment, the transparency of trade regulations and rules, fair competition, safety values, reciprocity, and enforceable and binding commitments. Nevertheless, 
the WTO allows for certain exceptions, in particular: preferential treatment for developing countries and bilateral and regional trade agreements existing outside the WTO. Currently, many countries are strongly motivated to join the Organization not only because of the possibility of expanding access to foreign markets, but also to accelerate domestic economic reforms and promote market economy and entrepreneurship (Allee, Elsig and Lugg 337-345).

\section{The Doha Round fiasco and its effects on the WTO system}

Since the collapse of the Multilateral Negotiation Round in Doha, which began in 2001, many observers have questioned the effectiveness and efficiency of the WTO. Still, the member states have not developed a joint and comprehensive multilateral agreement on trade liberalization and other required principles. Especially, the most expended differences concern the position of the US, the European Union, and the developing countries toward agriculture, industrial tariffs, non-tariff barriers, services, and trade remedies. In contrary, the emerging economic powers such as India, China, and Brazil postulate the need to lower agricultural tariffs, subsidies between developed countries, and protection of their services. On the other hand, developed countries strive for mutual liberalization of trade and, above all, to increase access to industry and services while protecting agricultural sectors (Fergusson, World Trade Negotiations 103). However, the Doha negotiating round continued after the global financial crisis that began in 2007. So far, only one multilateral agreement has been worked out during the ministerial conference in Bali in 2013 (Meltzer online). The agreement between members of the WTO concerns The Trade Facilitation Agreement (TFA), which serves as a tool for accelerating and facilitating global trade by eliminating many customs procedures and reducing costs. Although, the TPA agreement is one of the only successes of the Doha negotiations yet, it is an important image booster for the WTO itself and its existing members (UNCTAD 2-3).

The existing disputes means that the rules of global trade and investment do not follow the global challenges of the international system, which are associated with the transformation of global supply chains and the development of technology (Bayoumi 3-6). Thus, nowadays governments of individual countries more often decide to create convenient free trade agreements (FTAs), which include only some WTO members, that weakens efficiency and threatens the very existence of the institution. Hence, future reforms should include issues regarding organization, procedures, and practices that would reduce the problem of the WTO members' inability to conclude new and reciprocal agreements. These issues are the major reasons why the US and the administration of President Donald Trump pointed toward the necessity to reform the WTO, particularly the Appellate Body (Johnson, How Trump..., 2019).

Established in 1995, this institution is a permanent arm of the WTO composed of seven people who deal with appeals against reports issued by individual panels in disputes brought by members. The US has consistently criticized the Appellate Body for conducting unprecedented lawsuits and taking too long (over 90 days) to make decisions. Yet, the biggest problem remains the Americans' frustration with unfavorable sentences. The Appellate Body has questioned the way US authorities conduct anti-dumping investigations for years. However, the Trump administration 
did not actually show the will to offset political losses (Bown online). It is remarkable that dissatisfaction with the WTO's practice is expressed also by European Union countries. Thus, there are still many questions about the subsequent American leadership in the global trading system. Trump's trade policy and the unilateral tariffs enforcement undermine both the dysfunctions of the dispute settlement system as well as the credibility of the system as a whole. It is worth remembering that the current shape of the WTO system is dynamically determined by the economic position of the EU and China (McBride and Chatzky online).

Another WTO ministerial conference in July 2020 in Kazakhstan seemed to be setting out future trade system reforms. However, it turns out that the construction and strengthening of the WTO are extremely demanding tasks, especially in the context of the global economic crisis of 2007 and its impact on economic interdependence. Moreover, the aforementioned trends cause growing multipolarity of the world economy, related inter alia, with the burgeoning role of the emerging markets. However, other dependencies that occur in the global economy are also important, including the proliferation of regional trade agreements (RTAs), which now affect all WTO members and increasing protectionist tendencies, especially in American trade policy. Additionally, the current escalation of trade conflicts in the world's largest economies burdens and prevents the development of a multilateral trade agreement. Further, the state of affairs is complicated by unresolved disputes, which concern the US in particular (Reinsch and Caporal online).

The most important authorized institution to represent the US trade interests in the WTO is the USTR (USTR, Website: WTO). In general, the USTR's most important functions include developing and recommending trade policy to the US President and conducting negotiations at both bilateral and multilateral levels. USTR activities are regulated through the inter-agency committee of The Trade Policy Staff Committee (TPSC) and The Trade Policy Review Group (TPRG) (USTR, Website: WTO). Thus, the relations of the US with the WTO are coordinated by the Office of USTR's WTO Multilateral Affairs (WAMA). Its crucial tasks include responsibility for trade negotiations, and above all, for the development of the Doha Round. Within the office, there are many specialist committees on: subsidies, anti-dumping measures, trade remedies, import permits, technical standards and barriers, trade, customs facilitation, public procurement, WTO accession, and preferential trade arrangements. Furthermore, WAMA is responsible for negotiations with other international institutions, likewise the Organization for Economic Cooperation and Development (OECD) (USTR, 2018, 6-7).

What is more, Congress has constitutional authority over foreign trade and sets the priorities and principles of US' trade negotiations agenda, and implements trade agreements through the legislation processes (US Constitution, 1789, Article I, online). Also, Congress oversees USTR and other executive agencies that participate in WTO meetings and enforces its obligations and goals. Therefore, the US principles and priorities for both GATT and WTO system have been reflected in the legislation of the Trade Promotion Authority (TPA) since 1974. The TPA, which in practice is called the "fast track" procedure, refers to the President's granting special commercial powers by Congress, which speeds up the examination of contracts and legislative procedures. In practice, TPA permissions change the voting process for an 'upand-down' system that does not require other corrections. In addition, they increase 
the credibility of the US President as a negotiator of trade agreements by implementing the deals in the right way and at the right time. The TPA status granted to Donald Trump was originally in force until July 1, 2018, but was extended to July 1, 2020 (Fergusson and Davis 1-4).

American trade law, in accordance with the principles of the GATT / WTO system, is regulated, among others, by the Tariff Act or the Smoot-Hawley Tariff Act of 1930, which authorizes the US to impose countervailing and anti-dumping duties (US Senate, online). Until now, such mechanisms were in line with WTO standards and norms, which also provides such provisions and trade policy instruments. Therefore, an important regulation is also the Trade Act of 1974, especially Section 201, which allows the US President to apply relief when a growing production could cause dysfunctions in domestic industry (Schwarzenberg 1-2). However, the most important part of the indicated Act is Section 301, which authorizes the USTR to act in connection with the activities of foreign entities in violation of a trade agreement that discriminates, burdens or restricts US trade. Taking into consideration the mentioned procedure, the legislative initiative is held by private employees, enterprises, and the USTR (Williams and Hammond 1-3).

\section{The US' status in the WTO}

In order to understand the mechanisms of relations between the US and the WTO, it is necessary to focus on identifying both the possibilities and limitations accruing to the American economy from participation in the institution (WTO, "United States..."). Obviously, due to its economic capital, the US has been a global trade leader since the creation of the GATT system. Hence, this country was responsible for shaping negotiations and establishing international commercial law that today reflects US internal trade legislation. The evolution of both the US' position and attitude to the WTO, as well as the reform of the institution itself, is the most important subject of interest to subsequent American legislatures. Furthermore, the norms and rules that result from belonging to the WTO regulate most of the US' trade relations on a global scale. It is worth noting that currently, around 65 per cent of the US' trade is not regulated by free trade agreements (Williams, U.S. Trade Policy..., 23). Taking into consideration the volume of mutual trade turnover, the exchange with major trading partners, including China, the European Union, Japan, and India, are regulated by the WTO rules. Therefore, according to the opinion of the Congress, the WTO is not only the foundation of the global trading system, but also that of US trade legislation and the main oversight function of their contracts. Most of the current US trade agreements, which go beyond the WTO system, are based on the letter of WTO law, and put simply, on their content as well (Council on Foreign Relations, 2005).

Considering the number of complaints, the US is currently the most active member of the WTO. However, complaints submitted to the Organization by the Donald Trump administration were not a foregone conclusion. Based on statistics, the US generally wins trade disputes at the WTO, especially those against Chinese trade practices. Therefore, Trump's statement that the US is losing disputes at the WTO is incorrect. From 2003 to 2016, the US challenged Chinese trade activities at 
the WTO about 23 times. American complaints about Chinese practices typically relate to anti-dumping and countervailing duties, and in particular to the methods of calculating dumping and subsidy margins. It is worth recalling that as many as 20 cases were won by the US. Three of them are still ongoing. On the other hand, China has won only one third of the cases brought against US action in the WTO. Regardless of what the President Trump said, 40 per cent of the US' complaints against China are resolved in a dynamic way through consultation (usually within eight months) (Schott online). By the end of 2019, the US filed 124 complaints against other Member States and were sued in 155 cases for violating WTO rules. According to the data, the majority of US' disputes addressed trade violations by China, in particular their policy of support for domestic industry, intellectual property abuse, and import restrictions. In comparison, during the presidency of Barack Obama, the US brought 25 cases to the WTO, of which 15 concerned trade law with China (The White House online). Although, many cases are still pending, seven of them to be precise, which concerned Chinese subsidies for agriculture and the aviation industry and import duties on steel, were won by the American delegation to the WTO. On the other hand, due to the fact that the Trump administration treated the WTO as virtually ineffective, it was decided to regulate Chinese violations of trade law outside the WTO system. Therefore, Trump started to impose unilateral tariffs on Chinese steel and aluminum and announced further retaliation measures that would affect investment restrictions (Schneider-Petsinger, Wang, Jie, Crabtree 3-4).

\section{Major American priorities toward the World Trade Organization}

According to the USTR President's Trade Policy Agenda, the main goal of the US trade policy is to ensure further liberalization and freedom of exchange. American commercial activities primarily serve domestic economic growth and job creation, promote reciprocity of contracts with trading partners, strengthen the production base and defense capabilities, as well as develop the agricultural and service export industry. Subsequently, the report points that these goals are to be achieved on the fundamental basis of bilateral rather than multilateral cooperation, and renegotiations and revision of existing trade agreements. Hence, the whole catalog of actions is aimed towards reducing unfair trading practices that decrease the competitiveness of US goods and enterprises on the global markets (USTR, 2018, 7-8).

In addition to general objectives, the USTR report indicates a number of important priorities of specific importance (Packard online). Furthermore, the crucial ones include: providing the US employees and enterprises with fair business competition opportunities both on the American domestic market and global markets; removing trade barriers that block US exports, in particular of agricultural products; maintaining the development balance of all sectors of the US economy production, services, agriculture as well as small businesses and entrepreneurs; enforcement of intellectual property protection law in a way that ensures profit for all property owners; enforcement of anti-dumping and import subsidies; enforcement of labor law provisions and the ban on imports of goods that were carried out as a result of forced work; limiting the possibilities of the WTO to an 
unfavorable interpretation of commercial law; updating current trade contracts; ensuring close cooperation between the economic potential of the US and national security (USCIB, 2019).

It is worth noting, however, that President Trump's attitude towards the functioning of the WTO and the very idea of free trade was highly skeptical. During the presidential campaign in 2016, attention was drawn towards Trump's desire to move away from the consensus supporting the liberalization of the international trade policy. On the other hand, at that time, still as a candidate for US presidency, Donald Trump postulated the necessity to introduce restrictions on the movement of people and international trade. There are probably two reasons for Trump's election success. First, the campaign's slogans proved accurate from the point of view of Americans' concerns about the future of the US economy - taking into account the issue of personal well-being. On the other hand, the issue of employment and the problem of relocation of jobs abroad played a significant role. However, ultimately the result of the 2016 presidential election should not be viewed solely in terms of economic factors. Hence, Trump's choice as president was determined by race, diversity, education, and age. During his four-year term in office, the president lived up to most of his election promises: he withdrew from the Trans-Pacific Partnership initiative, renegotiated the NAFTA and South Korea-United States (KORUS) agreements, imposed protective tariffs on steel and aluminum (bringing this to the level of national security priorities), and embarked on a trade war with China and European countries. Interestingly, Trump's electoral success turned out to be heavily dependent on the votes of white males living in high-unemployment areas. However, it turns out that supporting protectionism was not dependent on individual household problems. Voting behavior resulted primarily from voters' concerns about the future of America's global domination in the world economy, and thus the position of the white racial group in the US (Noland online).

\section{American trade and the WTO: major challenges}

The administration of President Donald Trump expressed many doubts about the role and future status of the WTO. There is still a question mark on whether US' leadership in the organization can be understood in the category of profit or loss for the American economy. At the Asia Pacific Economic Cooperation (APEC) Summit in November 2017, Trump signified personal skepticism about the function of the Organization, indicating its limited capacity beyond the sovereignty of member states and the enforcement of commercial law in practice. Therefore, in Trump's words could be perceived both a criticism of the Organization and the threats of a possible withdrawal of the US from the formal trading system. China's failure to comply with reforms, which was a necessary requirement for joining the Organization, remains a contentious issue for subsequent American administrations. Despite the circumstances, Trump assured that the priority for his administration would be the dynamic and effective development of a multilateral trade agreement within the WTO (Oxenford online).

As a result, the negotiating agenda of the Doha Round still remains the most important issue. The possibilities for developing a multilateral agreement stay controversial, 
particularly regarding the discipline of agricultural subsidies and the resolution of problems that relate to public stockholding programs. What is more, since the creation of the WTO in 1995, there have been many new restrictions related to trade barriers, which apply to dynamic technological progress. Taking into account many systemic changes the importance of digital commerce and state-owned enterprises is still a huge challenge for the global trading system and its law (Johnson, While Trump Isolates..., 2019). According to the US political discourse, the WTO is unable to meet the defiance of current and important emerging markets to the possibility of internal reforms. Thus, this remains the main reason why the US, together with the European Union countries and Japan, has been postulating the necessity for tightening of subsidy rules in non-market economies (Brown and Irwin, "Trump's Assault...").

Taking the aforementioned into consideration, the USTR indicates a package of necessary reforms of the WTO, which include: a) regulation and adaptation of responses to the challenges arising from non-market economies; $b$ ) ensuring that the decisions of sovereign members of the organization are respected in matters of dispute resolution; c) introducing an obligation to inform WTO members about subsidies applied; and d) reassessing the status of developing countries. According to the USTR opinion, the possibility of carrying out the indicated reforms will positively affect the flexibility and effectiveness of WTO operations, particularly if other members of the Organization drew attention to the problems identified, especially the European Union and Canada (Fergusson, World Trade Organization online).

Anyway, the reform of the dispute resolution system remains the most complicated challenge for the US administration. To influence the possibilities of reform, the Trump administration decided to block the appointment of new judges to the seven-member WTO Appellate Body, which deals with members' contentious issues appeals. The term of office of two-thirds of the members of the Body expired on December 10, 2019. Since that time, the crisis that prevents effective enforcement of the Organization's provisions, has not ended. Subsequently, another challenge for both the WTO and the US systems is the problem of unilateral enforcement actions. According to the Congressional Research Service's report, such solutions not only undermine the fairness of the organization, but also contribute to the emergence of new trade restrictions (Murrill 1-4).

Due to many procedural and substantive reasons, however, the likelihood of the US withdrawing from the WTO is negligible. First, such a bill would have to be approved by both houses of Congress - the Senate and the House of Representatives, which was unlikely owing to the balance of political forces in the United States during the Trump presidency. Moreover, the effects of such a decision and their practical consequences of internal and external significance are puzzling (Brown and Irwin, "What Might a Trump Withdrawal..."). The most important negative effects include the enormous economic impact. Mainly, as a non-WTO member, the US would not be able to use and practice its MFN status anymore. In reality, the Organization would no longer provide extensive rules on quotas, trade-related investment measures, or subsidies that counteract discrimination against American goods. Also, the WTO ensures the enforcement of intellectual property rights, which is an important factor for economic growth in the US economy. Hence, potentially leaving the WTO would allow uncontrolled and unilateral imposition of trade barriers and tariffs on American products. Moreover, the US' withdrawal 
could provide an impetus to the global proliferation of free trade agreements outside the WTO system (Cimino-Isaacs, Fefer and Fergusson 1-2).

\section{The US-China trade war and its consequences for the WTO system}

Trade relations with China remained the most potent challenge and the most contentious issue of Donald Trump's policy towards the WTO. China's accession to the WTO, which took place in December 2001, has been seen as the triumph of global trade liberalization for many years. Anyway, accession opportunities required tedious and extensive internal reforms that removed most of the trade restrictions. China's membership in the WTO began the process of their economic integration with the world system due to which Beijing is now an extremely important link in the global supply chain (Morrison 1-3). Although, almost after 20 years of participation in the Organization, China still does not comply with the recommendations for not implementing systematic economic reforms. Thus, Beijing does not apply to the WTO international commercial law, which not only negatively affects the global economy, but also primarily undermines the legitimacy and capabilities of the Organization itself (Grabowski and Stefanowski 82-84).

What is more, China's membership in the WTO consistently guarantees its economy an increase in lucrative trade on a global scale. According to data, from 2001 to 2018 , trade increased from $\$ 516.4$ billion to $\$ 4.1$ trillion. Despite the fact, it is worth noting that Chinese customs tariffs remain relatively unchanged at 4.8 per cent between 2003 and 2017 (World Trade Statistical Review 23). Due to trade disputes with the US and reservations expressed by the Donald Trump administration, the Chinese government decided to gradually increase tariffs since 2018. Such a policy militates against, among others, Article 2 of the WTO Accession Treaty, which obliges Beijing to limit government intervention in the economy, as well as to open the market to trade in services, eliminate subsidies for exports, and enable markets to set prices. That is why China's progress towards a market economy is not only controlled by WTO authorities, but is also monitored by the USTR, which executes its own annual report on Chinese reforms for the US Congress. Moreover, it is worth emphasizing that, compared to membership in other organizations, such as the United Nations Security Council or the IMF, China's role in the WTO is very limited due to the costs of commercial disputes and gaps in specialized technical and legal knowledge (Meltzer and Shenai 1-5).

Subsequently, the course of China's economic policy is a major source of tension between many WTO members, in particular the European Union and the US. Moreover, Chinese dumping and government subsidies, which increase their global production capacity of aluminum, steel, and solar panels, are currently the matters of crucial importance for the most influential members of the WTO. It is remarkable that the problem is so widespread because it concerns the second largest global economy that could cause further transformation of world markets. Other controversial issues include granting the Chinese economy the status of a "developing country", which provides Beijing with some additional privileges and various benefits - including technical support towards settling disputes within the WTO. Some advanced 
economies are opposed to describing China as a developing economy. Therefore, in February 2019, Donald Trump proposed another set of reforms to the WTO, which would constitute much more stringent requirements for developing economies in general (Oleynik online). Despite this, the Chinese government has collaborated with eight other developing countries to reject the US proposal. Moreover, the source of tension between Washington and Beijing was Trump's attitude towards WTO institutions, in particular the importance and future of the Appellate Body. However, some noted that President Trump's defiant position strengthened China's role in the Organization and made it a new defender of free trade, which in future could be seen as further affecting the influence of the WTO (CSIS, 2020, online).

Although, President Xi still stresses the implementation of reforms and China's involvement in the creation of a transparent trade system in the international forum, Beijing has still not fulfilled its key WTO commitments. That is why the Chinese economic model with strong state interventionism remains a strong deterrent. The government continues to regulate both public and private enterprises preventing the identification of proper legal status and the adaptation of relevant legal rules under the WTO. Also, Beijing controls the administrative and judicial system, often using non-systemic or "informal" solutions. Until now, the WTO is unable to meet the challenges arising from the Chinese economy's failure to adapt to the general rules of international trade law (Kennedy 14-19). However, some point out that the WTO's ineffectiveness is due to its dependence on the position of the US, which has the strongest status in the Organization. It is also worth emphasizing that, in fact, the major WTO values and principles reflect American commercial interests: nondiscrimination, transparency, and the rule of law. Therefore, the indicated set of norms is the expanded challenge for the possibilities and effectiveness of reforms in the Chinese economy (Abiad, Baris and Bernabe 4)

Sino-American trade conflicts have escalated systematically since 2018. At the end of 2019, Trump threatened to introduce additional customs tariffs for all Chinese imports. It is the international system that ultimately suffers from such competition, which is constantly slowing down economic growth - particularly the financial markets. In order for the matter to be settled under the WTO system, it is necessary to introduce new solutions that would make it possible to make way for provisions regarding: Chinese state-owned enterprises, government subsidies, and digital commerce (Williams, Trump administration... 23). According to the Brookings Institution's report, which points to key contentious issues in the described trade relations, the required reforms include: 1) The need for close cooperation between the US and its allies to limit and control China's non-market trade activities that are incompatible with the WTO system; 2) The US should lead the control of Chinese reforms within the WTO to ensure implementation of the commitments under the Accession Protocol; 3) The possibilities of resolving trade disputes with China under the WTO system are closely dependent on the internal and institutional reform of the system, particularly the dispute resolution mechanism and the functioning of the Appellate Body (Meltzer and Shenai 1-4). Thus, SOE regulation remains the most important issue.

The basis governing mutual trade relations, therefore, should be a bilateral agreement that would address valid elements, such as digital commerce, technology transfer, and state-owned enterprises. Hence, on January 15, 2020, Chinese Deputy Prime Minister Liu He and the US President Donald Trump signed the Phase One Trade Deal, 
which was in force until February 14, 2020. It was focused on intellectual property rights, financial services, food and agricultural products, exchange rates and transparency, technology transfer, and digital commerce. In addition, the agreement lowered some US tariffs on Chinese goods in exchange for a promise to increase imports of American industrial, energy, and farm goods (Lawder, Shalal and Mason online).

\section{Conclusion}

The WTO remains a leading international institution that regulates and controls global exchange. Although, the system has been carrying out its tasks since the end of World War II, the $21^{\text {st }}$ century brought many challenges and impediments that limit the current functioning of the WTO. Furthermore, the challenges include systemic factors related to transformations of the global trade structure as well as internal policies of individual members. Since the creation of the GATT system, the US has played the most significant role in the global trading system. Two points are significant in this regard. On the one hand, the US is a country with a high degree of technological and economic development and potential. In addition, the US is the major advocate and guardian of the so-called Liberal World Order. Established at the beginning of the second half of the $20^{\text {th }}$ century, the system complied with the assumptions of the neoliberal doctrine, put into force the institutionalization of international relations, and pointed to the important role of commercial interdependence. Although American foreign policy has been dominated by the idea of liberalization and free trade for many years, the priorities of President Donald Trump's strategy were pivoted towards protectionist practices. That is why the Trump administration's actions undermined the possibilities and future functioning of the WTO. Hence, the main challenges included the importance of dynamic technological development of the world system, which stands out of the current WTO legal system. The status of emerging markets and developing countries, which often use unfair trade policy measures, remains a contentious issue. What is more, the recurrent US-China rivalry also weakens the WTO's ability to continue to respect and execute commercial law and the existing dispute resolution system. Due to its position, the US uses the WTO to pursue its own economic interests, which mainly focuses on limiting China's position. The aforementioned practices result in the dynamic spread of regional trade agreements that go beyond the WTO system. Despite this, the current economic interdependence in global terms rather reduces the risk of withdrawal of members or the collapse of the WTO in the future.

\section{References}

Abiad, Abdul, Baris, Kristina, Bernabe, John Aarvin. The Impact of Trade Conflict on Developing Asia. Mandalyuong: Asian Development Bank, 2018, http://dx.doi.org/10.22617/ WPS189770-2.

Allee, Todd, Elsig, Manfred, Lugg, Andrew. "The Ties between the World Trade Organization and Preferential Trade Agreements: A Textual Analysis." Journal of International Economic Law (2017), 20 (2), pp. 337-345, https:/ / doi.org/10.1093/jiel/jgx009. 
Baldwin, David. Neorealism and Neoliberalism: The Contemporary Debate. New York: Columbia University Press, 1993.

Bayoumi, Tamim. The WTO Doha Trade Round - Unlocking the Negotiations and Beyond. Washington D.C.: International Monetary Fund, 2011.

Bernhofen, Daniel and Brown, John. "An Empirical Assessment of the Comparative Advantage Gains from Trade: Evidence from Japan." American Economic Review (2005), Vol. 1, p. 7, https://doi.org/10.1257/0002828053828491.

Bouet, Antoine and Laborde, David. The Potential Cost of a Failed Doha Round. Washington D.C.: International Food Policy Research Institute, 2008.

Brown, Chad and Irwin, Douglas. "Trump's Assault on the Global Trading System." Foreign Affairs (2019), https://www.foreignaffairs.com/articles/asia/2019-08-12/trumpsassault-global-trading-system, last accessed 15 February 2020.

Brown, Chad and Irwin, Douglas. "What Might a Trump Withdrawal from the World Trade Organization Mean for US Tariffs?." Peterson Institute for International Economics (2018), https:/ / www.piie.com/publications / policy-briefs/what-might-trump-withdrawalworld-trade-organization-mean-us-tariffs, last accessed 15 February 2020.

Budnikowski, Adam. Międzynarodowe Stosunki Gospodarcze, Warszawa: PWE, 2006.

"Center for Strategic International Studies - China Power Team" (2019). How influential is China in the World Trade Organization?, https://chinapower.csis.org/china-world-tradeorganization-wto/, last accessed 15 February 2020.

Cimino-Isaacs, Cathleen, Fefer, Rachel and Fergusson, Ian. The World Trade Organization. Washington D.C.: Congressional Research Service, 2019.

"Council on Foreign Relations - CFR". "World Trade Organization" (2005), https://www.cfr. org/backgrounder/world-trade-organization, last accessed 15 February 2020.

Eichengreen, Barry and Irwin, Douglas. "The Slide to Protectionism in the Great Depression: Who Succumbed and Why?." The Journal of Economic History (2010), 70 (4), pp. 871-880, https:/ / doi.org/10.1017/S0022050710000756.

Fergusson, Ian. World Trade Negotiations: The Doha Development Agenda. Washington D.C.: Congressional Research Service, 2011.

Fergusson, Ian. World Trade Organization. Washington D.C.: Congressional Research Service, 2019.

Fergusson, Ian and Davis, Christopher. Trade Promotion Authority (TPA): Frequently Asked Questions. Washington D.C.: Congressional Research Service, 2019.

Goldstein, Judith, Rivers, Douglas, Tomz, Michael. "Institutions in International Relations: Understanding Effects on the GATT and the WTO on World Trade." International Organization (2007), 61 (1), pp. 37-45, https:/ / doi.org/10.1017/S0020818307070014.

Grabowski, Marcin and Stefanowski, Jakub. "The Chinese Belt Road and Road Initiative from the Central European Perspective Rhetoric versus Reality." Stosunki Międzynarodowe (2018), 4(54), pp. 67-84.

Jackson, Robert and Sorensen, Georg. Introduction to the International Relations: Theories and Approaches. Oxford: Oxford University Press, 2015, https://doi.org/10.1093/ hepl/9780198707554.001.0001.

Johnson, Keith. "How Trump May Finally Kill the WTO?." Foreign Policy (2019), https:/ / foreignpolicy.com/2019/12/09/trump-may-kill-wto-finally-appellate-body-world-tradeorganization/, last accessed 15 February 2020.

Johnson, Keith. “While Trump Isolates the U.S., It's 'Let Make a Deal' for the Rest of the World." Foreign Policy (2019), https:/ / foreignpolicy.com/2019/07/03/while-trump-isolates-u-s-its-lets-make-a-deal-for-the-rest-of-the-world-trade-fta-mercosur-eu/, last accessed 15 February 2020.

Kennedy, Scott. Global Governance and China: The Dragon's Learning Curve. London: Routledge, Taylor \& Francis Group, 2018. 
Keohane, Robert and Martin, Lisa. "The Promise of Institutionalist Theory." International Security (1995), Vol. 20, p. 39.

Keohane, Robert. After Hegemony: Power and Discord in the World Political Economy. New Jersey: Princeton, 1984.

Lawder, David, Shalal, Andrea, Mason, Jeff. "What's in the U.S.-China Phase 1 Trade Deal", Reuters (2020), https:/ / www.reuters.com/article/us-usa-trade-china-details-factbox/whatsin-the-u-s-china-phase-1-trade-deal-idUSKBN1ZE2IF, last accessed 15 February2020.

Mania, Andrzej and Pugacewicz, Tomasz (eds). Global Politics in the 21 $1^{\text {st }}$ Century: Between Regional Cooperation and Conflict. Berlin: Peter Lang Verlag, 2019.

McBride, James and Chatzky, Andrew. "What's Next for the WTO?." Council on Foreign Relations (2019), https://www.cfr.org/backgrounder/whats-next-wto, last accessed 15 February 2020.

Matasushita, Mitsuo, Schoenbaum, Thomas, Mavroidis, Petros. The World Trade Organization: Law, Practise and Policy. New York: Oxford University Press, 2014.

Meltzer, Joshua. "The 2013 WTO Bali Ministerial: Prospects and New Horizon." Brookings Institution (2013), https:/ / www.brookings.edu/blog/up-front/2013/11/25/the-2013-wtobali-ministerial-prospects-and-new-horizons/, last accessed 15 February 2020.

Meltzer, Joshua and Shenai, Neena. The U.S.-China economic relationship: A comprehensive approach. Global Economy and Development, Washington D.C.: Brookings Institution, 2019.

Morrison, Wayne. Enforcing U.S. Trade Laws: Section 301 and China. Washington D.C: Congressional Research Service, 2019.

Murrill, Brandon. The WTO's Appellate Body Loses Its Quorum, Is This the Beginning of the End for the "Rules-Based Trading System"? Washington D.C.: Congressional Research Service, 2019.

Noland, Marcus. "Protectionism under Trump: Policy, Identity and Anxiety." Peterson Institute for International Economics (2019), https:/ / www.piie.com/blogs/trade-investmentpolicy-watch/protectionism-under-trump-policy-identity-and-anxiety, last accessed 15 August 2020.

Oleynik, Ronald. "Trump Administration Aims to Reform WTO's Developing-Country Status." Holland \& Knight (2019), https://www.hklaw.com/en/insights/publications/2019/08/trump-administration-aims-to-reform-wtos-developing-country-status, last accessed 15 February 2020.

Oxenford, Matthew. "Trump Has Shown How Dangerous He Is to the Global Trading System." Chatham House (2018), https:/ / www.chathamhouse.org/expert/comment/trumphas-shown-how-dangerous-he-global-trading system?gclid=EAIaIQobChMItJf1j57j5wIV xIGyCh3W8AhuEAAYASAAEgJWo_D_BwE, last accessed 15 February 2020.

Packard, Clark. "Trump's real Trade War is Being Waged on the WTO." Foreign Policy (2020), https:/ / foreignpolicy.com/2020/01/09/trumps-real-trade-war-is-being-waged-on-thewto/, last accessed 15 February 2020.

Peterson Institute for International Economics. (2009). "Has U.S. Comparative Advantage Changed? Does This Affect Sustainability?." Washington D.C., p. 29.

Reinsch, William and Caporal, Jack. "The WTO's First Ruling on National Security: What Does It Mean for the United States?." Center for Strategic International Studies (2019), https:/ / www.csis.org/analysis/wtos-first-ruling-national-security-what-does-it-meanunited-states, last accessed 15 February 2020.

Ricardo, David. On the Principles of Political Economy and Taxation. London: Batoche Books, 1817.

Rymarczyk, Jan. Międzynarodowe Stosunki Gospodarcze. Warszawa: Polskie Wydawnictwo Ekonomiczne, 2006.

Schneider-Petsinger, Marianne, Wang, Jue, Jie, Yu, Crabtree, James. US-China Strategic Competition. The Quest for Global Technological Leadership. London: Chatham House. The Royal Institute of International Affairs, 2019. 
Schott, Jeffrey J. "In US-China Trade Disputes, the WTO Usually Sides with the United States." Ptereson Institute for International Economics" (2019), https:/ / www.piie.com/blogs/tradeand-investment-policy-watch/us-china-trade-disputes-wto-usually-sides-united-states, last accessed 9 September 2020.

Schwarzenberg, Andres. Section 301 of the Trade Act of 1974. Washington D.C.: Congressional Research Service, 2020.

Simmons, Beth and Martin, Lisa. "International Organizations and Institutions," in Walter Carlsneas, Thomas Risse-Kappen, Beth Simmons (eds.) Handbook of International Relations. Thousand Oaks: Sage Publications, 2002.

"The White House." Fact Sheet: The Obama Administration's Record on the Trade Enforcement (2017), https://obamawhitehouse.archives.gov/the-press-office/2017/01/12/fact-sheetobama-administrations-record-trade-enforcement, last accessed 15 February 2020.

UNCTAD. (2017). "Next steps upon the entry into force of the WTO Trade Facilitation Agreement." Technical Note No. 24, Washington D.C., pp. 2-3.

"Lays Out Priorities for WTO Modernization." United States Council for International Business (2019), https://www.uscib.org/uscib-lays-out-priorities-for-wto-modernization/, last accessed 15 February 2020.

"United States Senate". The Senate Passes the Smoot-Hawley Tariff, https://www.senate.gov/ artandhistory/history/minute/Senate_Passes_Smoot_Hawley_Tariff.htm, last accessed 15 February 2020.

U.S. Constitution (1789), https://www.senate.gov/civics/resources/pdf/US_ConstitutionSenate_Publication_103-21.pdf s. 1-2, last accessed 15 February 2020.

USTR. World Trade Organization. Washington D.C.: International Trade Commission, 2014.

USTR. Trade Policy Agenda of 2018. Washington D.C., 2018.

USTR, Website: WTO. World Trade Organization, https://ustr.gov/issue-areas/trade-organizations/world-trade-organization-wto, last accessed 15 February 2020.

VanGrasstek, Craig. The History and Future of the World Trade Organization. Geneva: World Trade Organization, 2013, https:/ / doi.org/10.30875/14b6987e-en.

Williams, Brock. U.S. Trade Policy: Background and Current Issues, Washington D.C: Congressional Research Service, 2019.

Williams, Brock. Trump Administration Tariff Actions (Sections 201, 232, and 301): FAQs. Washington D.C.: Congressional Research Service, 2019.

Williams, Brock and Hammond, Keigh. Escalating U.S. Tariffs: Timeline. Washington D.C.: Congressional Research Service, 2020.

World Trade Organization. Chronological list of disputes cases (2020), https:/ / www.wto.org/ english/tratop_e/dispu_e/dispu_status_e.htm, last accessed 25 August 2020.

World Trade Organization. "Promoting trade inclusion in the least developed countries through connectivity", Geneva, 2014.

World Trade Organization. "Trade Policy Review Report by the United States", Geneva, 2018.

World Trade Organization. "World Trade Statistical Review of 2019", Geneva, 2019.

WTO. “About WTO”, https://www.wto.org/english/thewto_e/thewto_e.htm, last accessed 15 February 2020.

WTO. “United States of America and the WTO”, https://www.wto.org/english/thewto_e/ countries_e/usa_e.htm, last accessed 15 February 2020.

Xie, Sherman. "Why Comparative Advantage is A Problematic Guide to Practical Policy?." Economic Affairs, 2010, 39 (2), pp. 243-250, https:/ / doi.org/10.1111/ecaf.12347. 